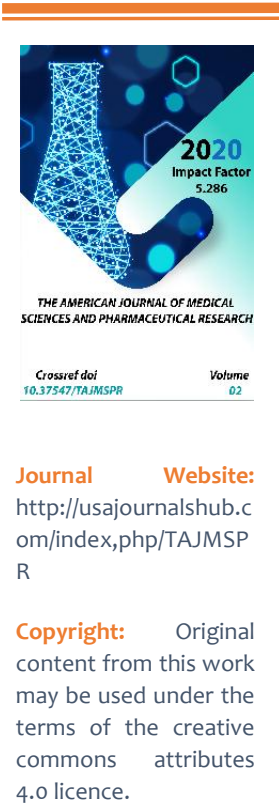

\title{
Application Of The Lutein Complex In Patients With Myopia And Computer Visual Syndrome
}

\author{
Kakharova Dildora Maribzhanovna \\ Andijan State Medical Institute, Uzbekistan \\ Mamadieva Mahliyo Sobirkhodzhaevna \\ Andijan State Medical Institute, Uzbekistan \\ Madaminkhuzhaeva Dilafruz Kahramonjon qizi \\ Andijan State Medical Institute, Uzbekistan
}

\section{ABSTRACT}

The term "computer vision syndrome" refers to eye symptoms caused by prolonged use of a computer. This pathology is mainly recorded in young people. It has been shown that the use of the lutein complex in the syndrome of computer stress and myopia significantly increases visual acuity and improves the quality of life of patients.

\section{KEYWORDS}

Lutein, myopia, computer visual syndrome, intraocular pressure, visual acuity.

\section{INTRODUCTION}

The term "computer visual syndrome" (CVS) includes a complex of visual and eye symptoms that appear due to prolonged work at the computer. The medical and social significance of this problem is great, since the pathology develops in people of young working age. The main reason for the development of GLC is overstrain of the accommodative apparatus of the eye due to the fact that the image on the computer monitor is fundamentally different from the image on paper and is often small in size. The main symptom of GLC is asthenopia, the manifestations of which are sometimes painful for the patient and have a negative impact on his quality of life. An integrated approach to the treatment of GLC includes not 
only prophylactic medication and non-drug measures aimed at possible elimination of the causes of GLC, but also the use of antioxidant drugs.

Purpose of the study: to assess the effect of the Lutein-complex drug on the main visual functions and quality of life in patients with myopia and GLC.

\section{MATERIAL AND METHODS}

A prospective randomized controlled trial was conducted from May to October 2018 at the Andijan Regional Eye Hospital. The criteria for the inclusion of patients in the study were: the presence of mild and moderate myopia and an established diagnosis of GLC; age 18-30; signing an informed consent to participate.

The criteria for excluding patients from the study were: opacity of the optical media of the eye and refractive errors that prevent computerized perimetry (for example, highgrade ametropia); the presence of concomitant ophthalmic pathology that affects visual function (for example, chorioretinal dystrophy); the presence of emmetropia or hyperopia on the paired eye; the presence of concomitant somatic diseases (diabetes mellitus, the consequences of cerebrovascular accident, etc.).

In accordance with the specified criteria, 60 people (120 eyes) were selected, which, in the process of randomization by the envelope method, were divided into 2 groups (main and control), 30 people (6o eyes) in each. Patients of the main group received the study drug lutein complex, 1 tablet 2 times a day for 6 months. (the drug was provided by the manufacturer to all patients free of charge). The active components of the Lutein complex are: Lutein - $4 \mathrm{mg}$, zinc - $10 \mathrm{mg}$, vitamin E - 30 $\mathrm{mg}$, vitamin A - $660 \mathrm{mcg}$, vitamin C - $200 \mathrm{mg}$, taurine - $100 \mathrm{mg}$, selenium - $30 \mathrm{mcg}$. The control group was under observation and did not receive the drug. Assessment of the state of the visual analyzer and quality of life was carried out before treatment (visit 1), after 3 months. after the start of the course of treatment (visit 2) and 6 months. from the start of treatment (visit 3). For this, the following methods were used:

1. Autorefractometry.

2. Visometry

3. Perimetry.

4. Tonometry. IOP was measured 3 times without the use of local anesthetics, the results were averaged.

5. The quality of life questionnaire contained the following items: headache; dizziness; blurred vision; burning sensation in the eyes; pain when moving the eyeballs; redness of the eyes; a feeling of heaviness in the eyeballs and eyelids.

Each answer was scored in points (from 0 to 3). To assess the severity of asthenopic complaints, the coefficient of visual asthenopia syndrome was calculated as the total severity for all objective symptoms of fatigue: o points - no symptoms of asthenopia; 1-3 points - asthenopia is poorly expressed; 46 points - moderate asthenopia; 7-10 points asthenopia is significantly pronounced.

\section{RESULTS}

The groups were comparable in terms of gender, age, and degree of myopia ( $p>0.05$; Table 1).

The study revealed significant changes in $\mathrm{OZ}$ in group 1 - there was a positive trend throughout the observation period. In the control group, the indicators remained unchanged (Fig. 1). 


\begin{tabular}{|c|c|c|c|c|c|}
\hline \multicolumn{6}{|c|}{ Clinical characteristics of patients in both groups. } \\
\hline \multirow{2}{*}{$\begin{array}{c}\text { Group / } \\
\text { average age }\end{array}$} & \multirow{2}{*}{$\begin{array}{c}\text { Number of } \\
\text { patients }\end{array}$} & \multicolumn{2}{|c|}{ Sex } & \multirow{2}{*}{$\begin{array}{c}\text { mild myopia } \\
\text { (from } 0.5 \text { to } \\
3 \text { D) }\end{array}$} & \multirow{2}{*}{$\begin{array}{c}\text { moderate } \\
\text { myopia } \\
\text { (from } 3.25 \text { to } \\
6 \text { D) }\end{array}$} \\
\hline & & female & male & & \\
\hline $1 / 26(+-) 0,3$ & 30 (60 eyes) & $21(70 \%)$ & $9(30 \%)$ & $14(46 \%)$ & $16(54 \%)$ \\
\hline $2 / 25(+-) 0,3$ & 30 (60 eyes) & $19(63 \% 3 \%)$ & $11(36,6 \%)$ & $15(50 \%)$ & $15(50 \%)$ \\
\hline All & 30 (60 eyes) & $40(66,6 \%)$ & $20(33,3 \%)$ & $29(48,3 \%)$ & $31(51,7 \%)$ \\
\hline
\end{tabular}

The IOP level in all patients was normal, averaging $16.3 \pm 0.2 \mathrm{~mm} \mathrm{Hg}$. Art. and remained stable throughout the observation period. The results of the computed perimetry also did not change.

The effect of the treatment was significantly manifested in an increase in the amplitude of the VECP-pattern after 3 months. therapy and subsequent stabilization of indicators during the remaining 3 months. study drug intake in group 1. In group 2, the results did not change (Fig. 2). The latency indices of the patternVESP of the retina and optic nerve remained unchanged for 6 months. of our observation in 2 groups and averaged $119 \pm 0.01 \mathrm{~ms}$.

All patients of the main group noted an improvement in the quality of life, which was manifested in a decrease in the number of points when filling out the questionnaire (Fig. 3). Patients reported a decrease in difficulties in daily activities, a decrease in blurred vision. By visit 2, complaints about "blurring of the contours of objects or letters of the text", "reddening of the eyes" decreased by 3 times, the ability to perceive objects at different distances increased significantly.

After 3 months. treatment marked the transition of asthenopia from moderate to mild, while in group 2, the degree of asthenopia remained moderate throughout the study.
During the entire observation period, there were no allergic reactions to the drug or any other undesirable effects.

\section{CONCLUSION}

While taking the drug Lutein-complex, patients with myopia and GLC revealed a significant increase in visual acuity, an increase in the amplitude of visual evoked cortical potentials, an improvement in the quality of life, which, along with a good tolerability of the drug, allows us to recommend regular courses of its administration, 1 tablet 2 r. / days for at least 3 months. patients with GLC in order to reduce the manifestations of asthenopia and improve visual functions.

\section{REFERENCE}

1. Rosenfield M. Computer vision syndrome: a review of ocular causes and potential treatments // Ophthalmic Physiol. Opt. 2011. Vol. 31 (5). P. 502-515.

2. American Optometric Association (AOA) [Электронный ресурс]. URL: http://www.aoa.org/patients-andpublic/caring-for-your-vision/protectingyour-vision/computer-vision-syndrome (дата обращения 19.01.2016).

3. [Brzheskij V.V., Egorova G.B., Egorov E.A. Dry eye syndrome and diseases of the eye surface: clinical course, diagnostics, treatment. M.: GEOTAR-Media, 2016:464 
(in Russ.)]. Бржеский В.В., Егорова Г.Б., Егоров Е.А. Синдром «сухого глаза» и заболевания глазной поверхности: клиника, диагностика, лечение. М.: ГЭОТАР-Медиа, 2016:464

4. [Brzheskij V.V. Dry eye syndrome in young people: unsolved problem of the modern time. Modern optometry. 2007;2(2):3843 (in Russ.)]. Бржеский В.В. Синдром «сухого глаза» у людей молодого возраста: нерешенная проблема современности. Современная оптометрия. 2007;2(2):38-43.

5. [Sutormina O.V. Organization of accommodative-vergence dysfunction diagnosis in computer vision syndrome // Herald of Tambov State University. 2012. Vol. 2. P. 632-637 (in Russian)]. Сутормина О.В. Организация диагностики аккомодационновергентных дисфункций при компьютерном синдроме // Вестн. Тамбовского гос. универ. 2012. № 2. С. 632-637

6. 2006. № 1. C. 38-40 [Nagorskii P.G. Antioxidants in the complex treatment of computer visual syndrome // RMJ Clinical Ophthalmology. 2006. Vol. 1. P. 38-40 (in Russian)]. Нагорский П.Г. Применение антиоксидантов в комплексной терапии компьютерного зрительного синдрома // РМЖ. Клиническая офтальмология.

7. 2009. № 3. С. 54-58 [Leshhenko I.A. Systems and rules for visual acuity measurement // Gazette optometry. 2009. № 3. P. 54-58 (in Russian)]. Лещенко И.А. О системах и правилах определения остроты зрения // Вестник оптометрии.

8. C. 21 [Ovechkin O.G., Pershin K.B. Antonjuk V.D. Functional correction of vision. SPb., 2003. P. 21 (in Russian)]. Овечкин О.Г., Першин К.Б. Антонюк В.Д.
Функциональная коррекция зрения. СПб., 2003. 